\begin{tabular}{c|l|l|l}
$\begin{array}{c}\text { Case Reports in } \\
\text { Neurology }\end{array}$ & $\begin{array}{l}\text { Case Rep Neurol 2010;2:69-73 } \\
\text { D0l: } 10.1159 / 000315621\end{array}$ & & $\begin{array}{l}\text { P 2010 S. Karger AG, Basel } \\
\text { ISSN 1662-680X } \\
\text { www.karger.com/crn }\end{array}$ \\
\hline
\end{tabular}

\title{
A Rare Malignant Triton Tumor
}

\author{
Kalpalata Tripathy ${ }^{\mathrm{a}}$ Rabinarayan Mallik ${ }^{\mathrm{b}} \quad$ Aparajita Mishra $^{\mathrm{a}}$

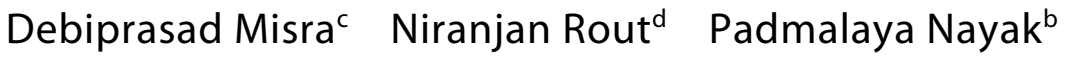 \\ Sagarika Samantray ${ }^{\mathrm{d}}$ Jayshree Rath ${ }^{\mathrm{a}}$ \\ aDepartment of Pathology, S.C.B. Medical College, Cuttack, bepartment of \\ Pathology, Kalinga Institute of Medical Science, Bhubanneswar, 'Department of \\ Pathology, MKCG Medical College, Berhmpur, and dDepartment of Pathology, \\ Acharaya Harihar Regional Cancer Institute, Cuttack, India
}

\section{Key Words}

Malignant peripheral nerve sheath tumor - Malignant triton tumor - Neurofibromatosis-1 . Rhabdomyoblast $\cdot$ S-100 protein

\begin{abstract}
Malignant peripheral nerve sheath tumor with rhabdomyoblastic differentiation, malignant triton tumor, has a rare incidence. We report such a case in a 40-year-old male who presented with a mass over the buttock. He was a previously diagnosed case of neurofibroma in the same area. Histomorphology supported by immunostaining with S-100 protein confirmed the diagnosis. Malignant triton tumor has a poor prognosis owing to its aggressive biological behavior. The fact that the presence of this tumor in the buttock region is extremely rare has prompted the authors to report this case.
\end{abstract}

\section{Introduction}

Malignant peripheral nerve sheath tumor (MPNST) accounts for about 5-10\% of all soft tissue sarcomas [1]. Malignant triton tumor (MTT) constitutes about $5 \%$ of all MPNSTs [2]. MTT is commonly seen in the head, neck, extremities and trunk [1-3]. Other rare locations are the buttock, visceras, retroperitoneum and mediastinum. Intracranial locations include the parieto-occipital lobe, lateral ventricle and cerebellopontine angle [1-3]. The fact that the presence of this tumor in the buttock region is extremely rare has prompted the authors to report this case. This is an interesting tumor not encountered very much in the neuro-oncology literature. It can occur in sporadic form or over a setting of neurofibromatosis-1 (NF-1). When MTT develops over NF-1, the diagnosis can be confirmed based on morphologic grounds supported by an immunostain such as S-100 protein. Desmin, myo-D1 and myogenin are immunostains positive for rhabdomyoblasts [2]. MTT has an aggressive biological behavior. Modern treatment has improved the prognosis of such cases [3]. 


\begin{tabular}{c|l|l|l}
$\begin{array}{c}\text { Case Reports in } \\
\text { Neurology }\end{array}$ & $\begin{array}{l}\text { Case Rep Neurol 2010;2:69-73 } \\
\text { Dol: } 10.1159 / 000315621\end{array}$ & & $\begin{array}{l}\text { Published online: June 1, 2010 S. Karger AG, Basel } \\
\text { ISSN 1662-680X } \\
\text { www.karger.com/crn }\end{array}$ \\
\hline
\end{tabular}

\section{Case Report}

A 40-year-old male presented with a large mass in the gluteal region gradually increasing in size over 6 months. Ten years back, operation of a nodule in the same area had revealed histopathological diagnosis of neurofibroma. On further questioning, the patient revealed having two small painful nodules over his back since the presence of the operated nodule. His family history suggested that his father was a diagnosed case of von Recklinghausen disease (NF-1). The resected mass consisted of a large globular mass measuring $10 \times 7 \times 6 \mathrm{~cm}$. The cut section showed solid grey-white and hemorrhagic areas (fig. 1). Multiple sections studied revealed alternate hypocellular and hypercellular areas composed of spindle cells with wavy nucleus and nuclear palisading. Thick-walled blood vessels were seen with perivascular accentuation of tumor cells in the hypocellular areas (fig. 2). Mitotic figures were brisk in the cellular areas, 11/10 high power fields with few abnormal mitoses. The tumor also showed a good number of scattered large cells both rounded and elongated with abundant deep eosinophilic cytoplasm and clearly visible cross striations (fig. 3). The spindle cells showed focal positivity for S-100 protein. The patient was subjected to radiotherapy on being referred to the oncology department. During a follow-up period of 8 months, the patient showed no evidence of recurrence or metastasis.

\section{Discussion}

MTT arises in two principal forms: sporadic or in association with NF-1. Slightly more than half of the cases of MTT have been reported in conjunction with NF-1 [1-3]. In our case, the tumor developed over a setting of NF-1. When it occurs in sporadic form, other spindle cell sarcomas like fibrosarcoma, malignant fibrous histiocytoma and rhabdomyosarcoma can come as differential diagnosis [3]. MTT with NF-1 shows marked male predominance with more predilections for younger age groups. The sporadic forms are seen in females of older age groups [4]. The tumor develops after a long latent period of 10-20 years. In our case the tumor developed after 10 years [1-4].

There is an agreement that the diagnosis of MPNST can be on morphologic grounds supported by positivity for S-100 protein. The morphologic features are (a) alternating hypocellular and hypercellular regions, (b) the appearance of thin wavy comma-shaped/ bullet-shaped nucleus in the hypocellular areas, (c) presence of nuclear palisading, (d) presence of nerve whorls or tactoid bodies resembling Wagner-Meissner corpuscles, (e) prominent thick-walled vasculature, and (f) presence of heterologous elements like rhabdomyoblasts, cartilage and bone. Such tumors show focal positivity for S-100 protein in $50-90 \%$ of cases, suggesting a nerve sheath origin. Rhabdomyoblasts are positive for immunostains such as desmin, myogenin and myo-D1 [1-4].

MTTs are tumors with a poor prognosis. The 5-year survival rate of MTTs is only $5-15 \%$ in contrast to MPNSTs where it is $50-60 \%$ [5]. Modern treatment has improved the prognosis of such cases. Radical excision followed by high-dose radiotherapy is the conventional mode of treatment. Some recent reports suggest that neoadjuvant therapy and adjuvant chemotherapy can eradicate micrometastasis. Integrated positron emission tomography and computed tomography have been used to assess remission and response to therapy [6]. The prognosis of MTT depends on the location, grade and completeness of surgical margins. It is good for the head, neck, extremities and worse for other sites including the buttock [7]. In a study it was observed that MTT in association with NF-1 has a poor prognosis compared to sporadic forms [3-7].

Recent works on cytogenetics have revealed some karyotypic changes associated with this tumor. There is a breakpoint in $11 \mathrm{p} 15$, considered a region of myogenic differentiation. This gene is probably responsible for rhabdomyoblastic differentiation. Amplification of c-myc oncogene is probably responsible for its aggressive biologic behavior [8]. 


\begin{tabular}{l|l|l|l}
$\begin{array}{c}\text { Case Reports in } \\
\text { Neurology }\end{array}$ & $\begin{array}{l}\text { Case Rep Neurol 2010;2:69-73 } \\
\text { D0I: 10.1159/000315621 }\end{array}$ & Published online: June 1, 2010 & $\begin{array}{l}\text { O 2010 S. Karger AG, Basel } \\
\text { ISSN 1662-680X } \\
\text { www.karger.com/crn }\end{array}$ \\
\hline
\end{tabular}

Fig. 1. Photograph of the cut open tumor mass measuring $10 \times 7 \times 6 \mathrm{~cm}$ with solid grey-white and hemorrhagic areas.

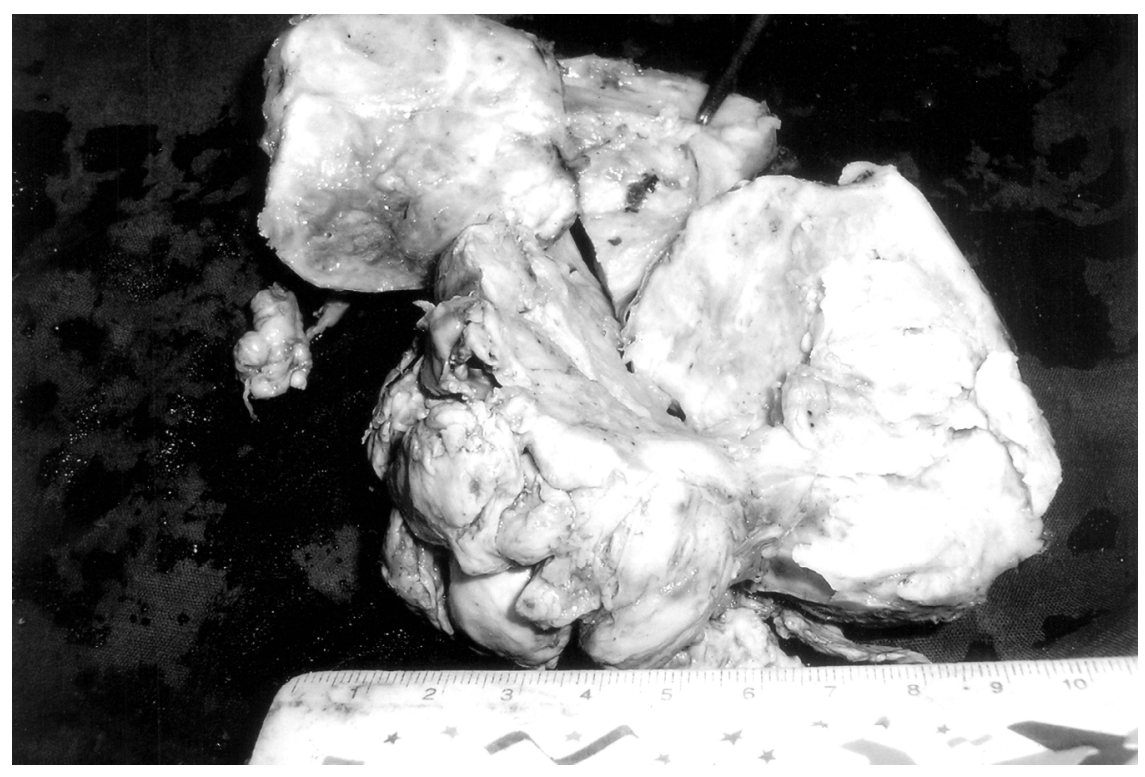

Fig. 2. Pictomicrograph showing hypocellular areas of the tumor with spindle cells having wavy nucleus, thick-walled blood vessels, perivascular accentuation of tumor cells and few rhabdomyoblasts. $\mathrm{H} \& \mathrm{E}, \times 200$

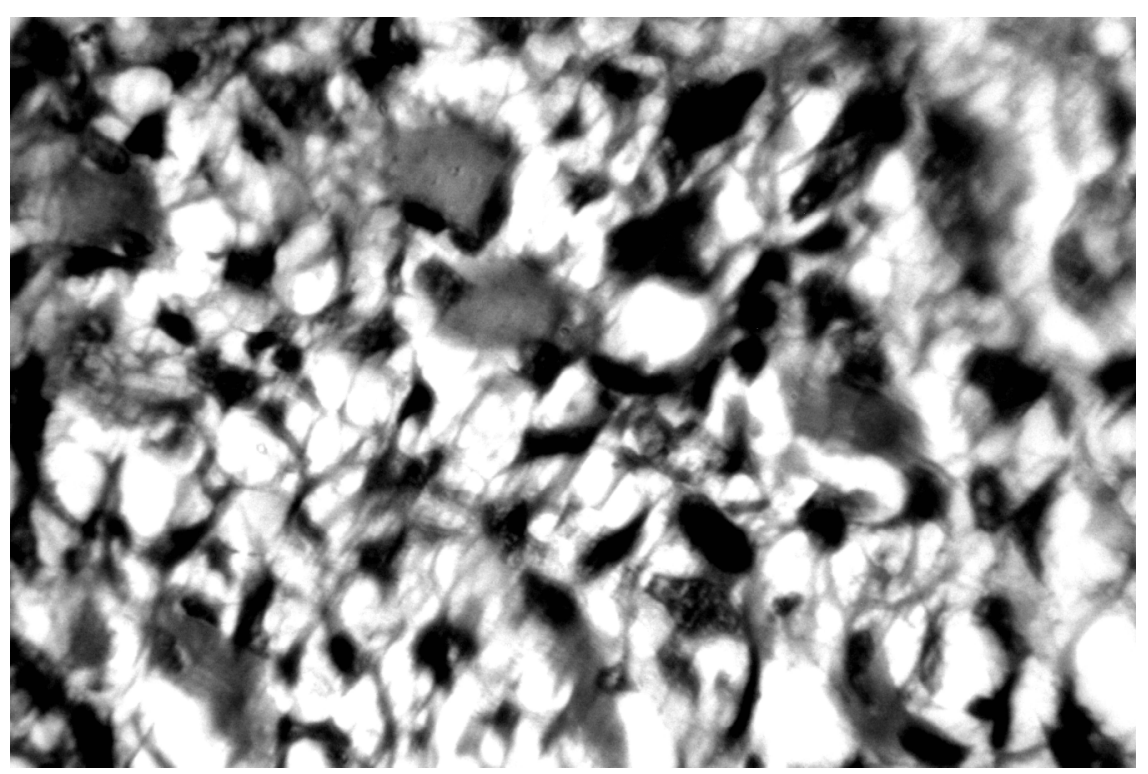


Fig. 3. Pictomicrograph of the tumor showing both elongated and rounded rhabdomyoblastic cells. $\mathrm{H} \& \mathrm{E}, \times 400$.

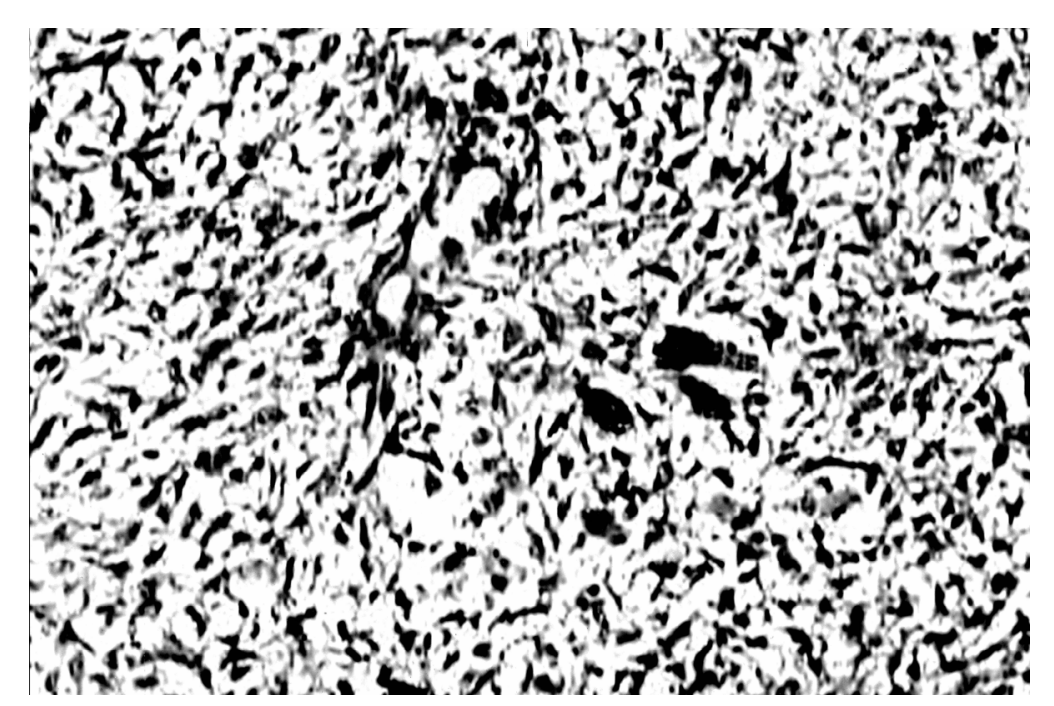




\begin{tabular}{c|l|l|l}
$\begin{array}{c}\text { Case Reports in } \\
\text { Neurology }\end{array}$ & $\begin{array}{l}\text { Case Rep Neurol 2010;2:69-73 } \\
\text { D0I: } 10.1159 / 000315621\end{array}$ & Published online: June 1, 2010 & $\begin{array}{l}\odot \text { 2010 S. Karger AG, Basel } \\
\text { ISSN 1662-680X } \\
\text { www.karger.com/crn }\end{array}$ \\
\hline
\end{tabular}

\section{References}

1 Weiss SW, Goldblum JR: Malignant tumors of peripheral nerves; in Weiss SW, Goldblum JR (eds): Enzinger and Weiss's Soft Tissue Tumors, ed 5. China, Mosby Elsevier, 2008, pp 903-944.

2 Brooks JSJ: Disorders of soft tissue; in Sternberg SS (ed): Diagnostic Surgical Pathology, ed 3. Philadelphia, Lipincott Williams and Wilkins, 1999, pp 131-221.

3 Zisis C, Fragoulis S, Rontogiani D, et al: Malignant triton tumor of the anterior mediastinum as incidental finding: a case report. Monaldi Arch Chest Dis 2006;65:22-24.

-4 Brooks JS, Freeman M, Enterline HT: Malignant triton tumors: Natural history and immunohistochemistry of nine new cases with literature review. Cancer $1985 ; 55: 2543-2549$.

5 Aldlyami E, Dramis A, Grimer RJ, et al: Malignant triton tumor of the thigh a retrospective analysis of nine cases. Eur J Surg Oncol 2006;32:808-810.

-6 Kudo M, Matsumoto M, Terao H: Malignant nerve sheath tumor of acoustic nerve. Ach Pathol Lab Med 1983;107:293-297.

-7 Yakulis R, Manack I, Murphy Al Jr: Post radiation malignant triton tumor: a case report and review of the literature. Arch Pathol Lab Med 1996;120:541-548.

8 Stasik CJ, Twafik O: Malignant peripheral nerve sheath with rhabdomyosarcomatous differentiation (malignant triton tumor). Arch Pathol Lab Med 2006;130:1878-1881. 